\title{
UJI EFEKTIFITAS FESES TERNAK (SAPI, KERBAU DAN KUDA). TERHADAP PRODUKSI BIOGAS YANG DIHASILKAN DI DUSUN BATU ALANG, SUMBAWA
}

\author{
${ }^{1}$ I Karman*, ${ }^{1}$ Khotibul Umam, ${ }^{1,2}$ Arief Budi Witarto \\ 1. Program Studi Teknobiologi Fakultas Teknobiologi Universitas Teknologi Sumbawa \\ ${ }^{2}$ Sains Technopark, Kabupaten Sumbawa \\ *Corresponding Author email: khotibul.umam@uts.ac.id
}

\begin{tabular}{|c|c|}
\hline \multirow[b]{2}{*}{ Diterima } & Abstrak \\
\hline & $\begin{array}{l}\text { Sumbawa, dengan jumlah populasi yang tinggi dapat menjadi salah satu alternatif dalam } \\
\text { pemenuhan kebutuhan energi di masyarakat, dengan memanfaatkan residu (feses) } \\
\text { ternak sebagai biogas. Tujuan dari penelitian ini untuk mengetahui jenis perlakuan yang }\end{array}$ \\
\hline Diterbitkan & $\begin{array}{l}\text { efektif dalam menghasilkan biogas. Metode yang digunakan dalam penelitian ini } \\
\text { disusun dengan menggunakan Rancangan Acak Lengkap (RAL) dengan empat } \\
\text { perlakuan dan tiga ulangan. Perlakuan menggunakan sampah sayur (SS), Feses Sapi } \\
\text { (FS), Feses Kerbau (FK), dan Feses Kuda (Fku). Fermentor berisi kotoran dan air }\end{array}$ \\
\hline $\begin{array}{l}\text { Keyword: } \\
\text { Biogas. }\end{array}$ & dengan perbandingan $1: 1$ difermentasi selama 13 hari. Melalui penelitian ini dilakukan \\
\hline Efektifitas, & Feses Sapi, Feses Kerbau, dan Feses Kuda. Hasil penelitian ini menujukkan bahwa feses \\
\hline Feses ,ANOVA & kerbau memiliki volume gas yang lebih tinggi yaitu sebesar $75 \mathrm{~cm}^{3}$ sedangkan dari \\
\hline One Way, & waktu fermentasi kontrol sebagai/ sampah sayuran menujukkan hasil yang lebih cepat \\
\hline & namun, tidak menghasilkan nyala api sebagai indikator kandungan biogas yang \\
\hline Significance & diharapkan dari penelitian ini. Secara berturut-turut volume gas yang dihasilkan yaitu \\
\hline Different (LSD) & sampah sayuran $35 \mathrm{~cm}^{3}$ Feses Sapi $45 \mathrm{~cm}^{3}$ Feses Kerbau $75 \mathrm{~cm}^{3}$ dan Feses Kuda $53 \mathrm{~cm}^{3}$ \\
\hline & hasil analisis yang dilakukan menggunakan ANOVA One Way dengan uji lanjut Least \\
\hline & $\begin{array}{l}\text { Significance Different (LSD) menunjukkan tidak adanya perbedaan signifikan dari } \\
\text { setiap perlakuan. Selain itu dilakukan juga uji nyala api yang hasilnya menunjukkan }\end{array}$ \\
\hline & $\begin{array}{l}\text { bahwa feses sapi yang memiliki waktu nyala terlama yaitu } 13 \text { detik dibandingkan dari } \\
\text { perlakuan lainnya. oleh karena itu, hasil penelitian ini menunjukkan bahwa penggunaan } \\
\text { feses sapi dalam produksi biogas lebih efektif dilihat dari uji nyala. }\end{array}$ \\
\hline
\end{tabular}

\section{PENDAHULUAN}

Pesatnya pertambahan populasi masyarakat dunia, telah menimbulkan banyak persoalan baru dalam banyak bidang kehidupan. Menurut Liun (2014), sektor yang paling terpengaruh oleh jumlah populasi adalah energi. Hal ini dikarenakan tingkat konsumsinya yang semakin besar yang akan berakibat pada kebutuhan sumber sumber energi yang besar pula. Secara umum, pemenuhan kuota energi saat ini bersumber dari energi tidak terbaharukan seperti minyak bumi, batubara, gas, dan lain sebagainya. Meningkatnya kebutuhan akan energi ini menyebabkan eksploitasi dan konsumsi energi semakin tinggi sedangkan cadangan energi dunia semakin menipis (Kementerian ESDM, 2013).

Sebagai sebuah negara kepulauan, populasi masyarakat yang terpisah oleh bentang laut menambah angka kebutuhan akan energi yang umumnya dimanfaatkan sebagai moda transportasi darat, laut, maupun udara. Saat ini, kebutuhan energi Indonesia masih bergantung pada energi yang berasal dari fosil, hal ini jika digunakan secara terus-menerus maka energi fosil ini akan semakin menipis dan berpotensi habis (Elinur,
2010). Selain itu, dampak penggunaan menimbulkan efek negatif pada lingkungan, seperti semakin banyaknya produksi gas karbon dioksida $\left(\mathrm{CO}_{2}\right)$. Sebagai akibatnya terjadi pencemaran lingkungan dan emisi rumah kaca yang kian meningkat (Hambali, et al 2007). Menurut Ir. Sulistyono (2014), salah satu cara untuk mengurangi penggunaan bahan bakar fosil yaitu dengan pemanfaatan sumber-sumber energi terbarukan yang sederhana namun berdampak besar bagi masyarakat, seperti bioenergi yang bersumber dari bahan organik. Di Indonesia, sumber sumber energi terbarukan pada dasarnya melimpah dan tersebar di semua wilayah, salah satunya yaitu di Sumbawa.

Sumbawa merupakan salah satu pulau di bagian timur Indonesia yang terkenal sebagai lumbung ternak nasional (Kompas, 2015). Pada tahun 2009, Sumbawa dicanangkan sebagai pulau sejuta sapi berdasarkan keputusan gubernur Tuan Guru Zainul Majdi (Kompas, 2009). Selain sapi, Sumbawa juga terkenal dengan hewan ternak lainnya seperti, kerbau, kambing dan kuda. Potensi ternak yang cukup besar di Sumbawa, dapat menjadi salah satu alternatif dalam pemenuhan kebutuhan energi di masyarakat, dengan 
memanfaatkan residu (feses) ternak sebagai Biogas. Menurut Adityawarman (2015), dalam penelitiannya, biogas yang dikembangkan dari feses sapi menunjukkan hasil yang optimal untuk keperluan memasak sehari-hari.

Berdasarkan pemaparan di atas, maka pemenuhan kebutuhan energi berbasis limbah ternak untuk menjadi biogas adalah solusi yang bisa ditawarkan untuk masyarakat Sumbawa. Hal ini bertujuan untuk membudayakan pola hidup sehat dan pemanfaatan energi bebasis potensi lokal ternak. Meskipun penelitian di bidang bioenergi sudah cukup banyak, namun belum ada yang mengarah ke studi komparasi efektifitas feses ternak yang digunakan dari berbagai jenis ternak. Oleh karena itu, penelitian yang berjudul Uji Efektifitas Feses Ternak (Sapi, Kerbau dan Kuda) terhadap Produksi Biogas di desa Batu Alang, Sumbawa penting untuk dilakukan.

Tujuan dari penelitian ini adalah untuk mengetahui variasi kandungan gizi D. hispida yang berasal dari beberapa wilayah di Pulau Bali dan Lombok, sehingga dapat direkomendasikannya tempat yang paling sesuai untuk budidayanya. Penelitian ini juga dilakukan untuk mengetahui apakah terdapat variasi genetika pada $D$. hispida yang mungkin dipengaruhi oleh perbedaan tempat tumbuh pada kedua pulau tersebut. Hal ini sangat penting dilakukan mengingat keberadaan jenis liar maupun yang telah dibudidayakan sangat penting untuk dilestarikan guna menjamin tersedianya plasma nutfah, sehingga usaha perbaikan kualitas tanaman bisa tetap dilakukan. Dari hasil penelitian ini juga nantinya akan diketahui apakah ada kaitan antara keragaman genetik pada $D$. hispida dengan lokasi tempat tumbuhnya serta fariasi kandungan gizi esensial dan kalsium oksalat yang dikandungnya.

\section{METODE PENELITIAN}

\section{Waktu dan Tempat}

Penelitian dilaksanakan mulai Januari sampai dengan Juni 2019. Penelitian dilaksanakan di kampus Universitas Teknologi Sumbawa J1. Raya Olat Maras, Dusun Batu Alang, Kecamatan Moyo Hulu, Kabupaten Sumbawa, Nusa Tenggara Barat.

Adapun alat yang digunakan pada penelitian uji efektifitas biogas pada feses botol fermentor 700 $\mathrm{ml}$ sebanyak 12 unit sesuai perlakukan, balon sebanyak 12 unit, gelang karet sebanyak 12, korek api, scaple atau cutter, ember, kantong plastik, ember, corong, sarung tangan, dan termometer. Adapun bahan yang digunakan pada pada penelitian uji efektifitas biogas adalah feses sapi, feses kerbau, feses kuda, sampah sayur, EM4 (Effective Microorganism-4) dan air.

\section{Perancangan botol fermentor dan pengisian fermentor}

Pembuatan digester sederhana ini dibuat dengan menggunakan botol bekas rakitan yang disesuaikan dengan kebutuhan. Perakitan ini dimulai dari pengumpulan peralatan yang dibutuhkan seperti botol bekas sebanyak 12 unit dengan ukur $1500 \mathrm{ml}$, balon sebanyak 12 buah, karet 12 buah dan lainnya. Selanjutnya sampel feses ternak sudah dimasukkan dalam botol fermentor, bagian mulut botol ditutup dengan menggunakan balon dan memastikan balon tidak bocor dan tidak mengembang sebelum terjadi proses fermentasi. Setelah itu, untuk memastikan balon tidak terlepas nantinya keliling mulut balon diikat menggunakan karet. Kemudian, masingmasing botol fermentor diberi label sesuai jenis sampel beserta ulangannya.

\section{Pelaksanaan}

Sampel yang telah dicampur air dengan perbandingan 1:1 dari isi total botol fermentor ditambah $700 \mathrm{ml}$ (berisi feses dan air). Selanjutnya sampel dimasukkan dalam botol fermentor. Rangkaian fermentor diadopsi dari fermentor biogas dalam (Mujahid, et al., 2013) dengan sedikit modifikasi yakni mulut botol ditutup dengan balon dan dipastikan benar-benar kempis ketika dipasang ke mulut botol yang dieratkan dengan karet. Selain itu, sebelum dimasukkan dalam ruang botol fermentasi balon dipastikan tidak bocor dan benar-benar dalam keadaan kempis ketika dipasangkan ke mulut botol karena jika terdapat udara maka akan mempengaruhi keakuratan hasil pengukuran. Masing-masing botol fermentor diberi label sesuai dengan perlakuan. Fermentor diinkubasi pada suhu ruang yang diikuti dengan mengamati skala pada termometer yang diletakkan dalam ruang inkubasi.

\section{Pengamatan Volume Gas}

Pengamatan dilakukan setiap hari selama 13 hari selama terjadinya proses fermentasi. Pengamatan dilakukan dengan mengukur keliling balon dengan sebuah tali. Kemudian hasil ukuran pada tali diukur menggunakan penggaris dengan satuan (cm). Data ukuran keliling balon kemudian digunakan untuk memperoleh volume biogas dalam balon. Volume gas dalam balon disumsikan sama dengan volume dalam bola. Jadi, volume gas dalam balon diperoleh dengan menggunakan persamaan berikut.

$$
\begin{aligned}
& \mathrm{v}=\frac{4}{3} \cdot \pi \cdot \mathrm{r}^{3} \\
& \mathrm{r}=\text { keliling balon } / 2 \pi \\
& \mathrm{V}=\text { Volume balon/gas dalam balon }\left(\mathrm{cm}^{3}\right) \\
& \pi=\text { phi, koefisien dengan nilai } 3,14 \\
& \mathrm{r}=\text { jari-jari lingkaran }(\mathrm{cm})
\end{aligned}
$$




\section{Pengamatan Nyala Api}

Gas metan yang telah tertampung dalam balon disulutkan pada nyala api lilin. Mulut balon langsung diarahkan ke api kemudian dibuka sedikit-sedikit agar nyala api tidak padam. Uji nyala api dikatakan positif ditandai dengan nyala api yang semakin besar dan tidak memadamkan lilin. Spesifikasi gas metan akan memperlihatkan nyala api berwarna biru. Lama nyala api diukur dengan menggunakan stopwatch.

\section{Analisis Data}

Analisis data dalam penelitian ini menggunakan perhitungan statistik dengan melihat dari hasil perhitungan Microsoft Excel. Selain itu, analisis data ini juga diperkuat dengan penggunaan analisis data one way ANOVA menggunakan aplikasi SPSS 22.0 untuk melihat perbandingan antara efektifitas gas metan yang dihasilkan dari masing-masing perlakuan feses satu dengan yang lainnya.

\section{Hasil Dan Pembahasan}

\section{Pengamatan Volume Gas}

Penelitian ini menggunakan 4 sampel dan masing-masing sampel terdiri dari feses sapi, kerbau, kuda dan sampah sayur sebagai kontrol. Setiap sampel pada penelitian ini dilakukan pengulangan masing-masing 3 kali. Selanjutnya pada pengujian tahap pertama yang dilakukan ialah mengamati perkembangan volume gas melalui uji mengembangnya balon. Volume gas diukur setiap hari dengan menggunakan tali dan penggaris untuk melihat ukuran lingkaran yang diperoleh dari balon yang mengembang. Pengamatan volume gas ini bertujuan untuk mengukur kadar gas (Biogas) yang dihasilkan dari masing-masing perlakuan.

Berdasarkan hasil pengamatan yang telah dilakukan selama 13 hari, gas yang dihasilkan melalui pengamatan parameter volume gas. Maka, diperoleh hasil sebagai berikut:

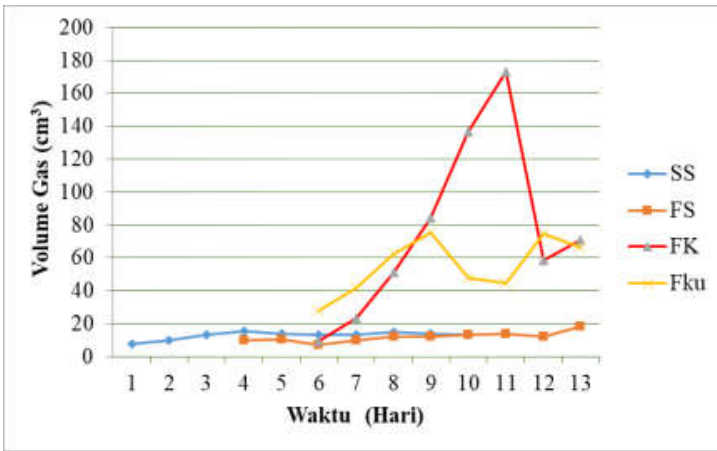

Gambar 4.1 Data Grafik pengamatan volume Gas. Perlakuan SS (Sampah Syur), FS(Fesese Sapi), FK (Feses Kerbau) dan FKu (Feses Kuda)
Gambar 4.1 menujukkan bahwa volume gas perlakuan sampah sayur (SS) di hari pertama sudah menunjukkan adanya volume gas yang ditunjukkan dengan adanya hasil ukuran volume lingkaran balon sebagai penampung gas pada perlakuan penelitian ini. Namun, hasilnya yang ditujukkan tidak stabil yakni biogas yang dihasilkan pada sampel sampah sayur ini hanya berlangsung hingga hari kesepuluh dan tidak signifikan. Menurut Sutrisno (2010) sampah sayur memiliki karteristik mudah membusuk, bersifat lembab dan memiliki kandungan air yang sedikit. Sehingga hal ini menyebabkan sampah sayur ini memiliki sifat mudah terdekomposisi secara cepat dan hal ini sangat berpengaruh cepat terjadinya proses fermentasi (Hardianto, 2008). Selain itu pada perlakuan sampah sayur (SS) ini ada penambahan bakteri EM4 (Effective Microorganism-4) sehingga hal ini membantu cepat terjadinya proses fementasi (Juanda et al., 2011).

Dari gambar 4.1 pada hari ke-11 terlihat perlakuan feses kerbau (FK) menunjukkan hasil rata-rata volume gas yang lebih tinggi dibandingkan dengan perlakuan lainnya. Hal ini menunjukkan bakteri anaerob pada perlakuan feses kerbau (FK) sedang berada pada fase pertumbuhan maksimal. Selain itu perbedaan volume gas yang dihasilkan pada masing-masing perlakuan sebagaimana yang diungkapkan I Made, et al., (2011) perbedaan tersebut disebabkan oleh perbedaan sifat fisik perlakuan yang digunakan. Hal yang sama diungkapkan Intan (2014), perbedaan jenis feses dari masing-masing fermentasi biogas akan berpengaruh pada produksi biogas. Hal ini menunjukkan bahwa variasi perlakuan sangat mempengaruhi produktivitas bakteri dalam memproduksi biogas. Ketiga variasi perlskuan yang digunakan memiliki sifat fisik yang berbeda dalam hal produktifitas bakteri pembentuk biogas dan mempengaruhi volume total biogas yang dihasilkan (Wahyuni, 2011).

Namun, disisi lain perlakuan feses sapi (FS) juga menunjukkan fermentasi yang lebih cepat daripada perlakuan feses kerbau dan feses kuda. Hal tersebut sebagaimana yang terlihat pada gambar 4.1 data grafik volume gas. Meskipun hasil volume gasnya tidak terlalu besar. Perlakuan feses sapi menunjukkan fermentasi yang lebih cepat karena feses sapi memiliki kandungan nutrisi makro yang seimbang sehingga proses fermentasinya lebih cepat (Sanjaya et al., 2015). Selain itu, feses sapi mengandung nutrisi makro yang diperlukan dalam pembuatan biogas. Nutrisi makro feses sapi juga memiliki kandungan nutrisi mikro berupa trace metal untuk pertumbuhan mikroorganisme dalam membantu penguraian feses menjadi gas metan (Zhang et al., 2014). Hal yang 
sama diungkapkan Mujahida (2013) feses sapi terdapat mikroba yang memilki peran penting dalam proses pembentukan biogas namun jumlah mikroba yang berperan belum mencapai pertumbuhan yang maksimal sebagaimana yang pada gambar grafik 4.1. Peningkatan volume gas perlakuan feses sapi cenderung konstan dan tidak signifikan.

Namun, pada hari ke-12 produksi volume biogas yang dihasilkan mengalami penurunan namun dihari ke-13 meningkat lagi. Fluktuasi yang terjadi pada produksi

volume biogas disebabkan karena penurunan konsentrasi nutrient pembentuk biogas seperti karbohidrat, lipida dan protein, bahkan juga vitamin dan mineral. Selain itu, penurunan rendemen produksi biogas juga disebabkan karena penurunan padatan terlarut medium (Rahayu, 2009). Selanjutnya untuk melihat perbedaan yang dihasilkan pada masing-masing perlakuan maka perlu dilakukan analisa data menggunakan SPSS One Way Anova. Berdasarkan lampiran 5 hasil uji SPSS menujukkan hasil sig sebesar 0,069 dengan 95\% tingkat kepercayaan. Hasil tersebut menujukkan tidak adanya perbedaan yang signifikan terhadap semua sampel. Dari hasil data analisis One Way Anova selanjutnya dilakukan perhitungan dengan menggunakan rumus rancangan acak lengkap. Perhitungan dilakukan untuk melihat uji lanjut yang akan digunakan. Hasil perhitungan tersebut diperoleh hasil nilai kuadrat korelasi (KK) sebesar 1,05. Dari hasil tersebut dapat diputuskan uji lanjut yang bisa digunakan ialah Least Significance Different (LSD).

Tabel 4.1 Hasil Uji Lanjut Least Significance Different (LSD) dengan (tingkat kepercayaan 95\%)

\begin{tabular}{cc}
\hline Perlakuan & Rata-rata \\
\hline 4 & $9,0633^{\mathbf{a}}$ \\
2 & $9,3300^{\mathbf{a b}}$ \\
1 & $9,6333^{\mathbf{b c}}$ \\
3 & $10,6767^{\mathbf{c}}$
\end{tabular}

Berdasarkan Tabel 4.1 sampel perlakuan 3 (Feses Kerbau) menujukkan hasil berbeda tidak nyata dengan kontrol perlakuan 1 (Sampah sayur). Begitupun jika perlakuan feses lain dibandingkan dengan perlakuan sampah sayur (SS) sebagai kontrol hasilnya pun tidak berbeda nyata. Jadi dari hasil uji lanjut Least Significance Different (LSD) antar semua perlakuan yang digunakan pada penelitian ini menunjukkan hasil yang tidak berbedah nyata. Hal ini berdasarkan cara baca hasil uji lanjut program SPSS (Bambang, 2010).

\section{Pengamatan Uji Nyala Api}

Untuk mengetahui adanya kandungan gas metan yang terdapat pada hasil fermentasi sampel feses maka dilakukan uji nyala. Selain itu uji nyala ini dilakukan untuk mengetahui lama waktu nyala api dari gas metan yang dihasilkan. Hasil uji nyala biogas dapat dilihat pada tabel 4.2.

Tabel 4. 2 Hasil Uji Nyala Masing-masing Perlakuan

\begin{tabular}{cc}
\hline Perlakuan & Waktu Nyala (S) \\
\hline SS & 0 \\
FS & 13 \\
FK & 6 \\
Fku & 3 \\
\hline
\end{tabular}

Keterangan : SS (Sampah Sayur), FS (Feses Sapi), FK(Feses Kerbau), Fku (Feses Kuda)

Berdasarkan tabel 4.2 dapat dilihat bahwa setiap perlakuan memiliki kemampuan waktu nyala yang berbeda. Seperti yang terlihat pada tabel 4.2 menghasilkan waktu nyala masing-masing Sampah sayur (SS) 0 detik, Feses Sapi (FS) 13 detik, feses kerbau (FK) 6 detik, dan feses kuda (Fku) 3 detik. Hasil uji nyala tersebut dapat diketahui perlakuan feses sapi (FS) menghasilkan waktu nyala yang lebih lama dibandingkan dengan perlakuan lainnya. Namun, jika dilihat dari kuantitas volume gas yang dihasilkan selama pengamatan 13 hari volume gas paling tinggi dihasilkan pada perlakuan feses kerbau tapi tidak berbeda nyata dengan volume gas yang dihasilkan oleh kontrol. Hal tersebut dibuktikan dari uji analisis SPSS One Way Anova dan uji lanjut Least Significance Different (LSD) dan dapat dilihat pada gambar 4.2.

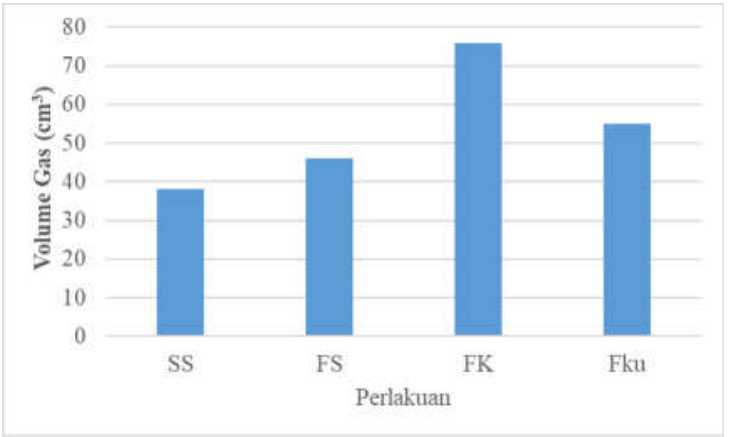


Gambar 4.2 Data Grafik volume Gas pada masingmasing perlakuan. Perlakuan SS (Sampah Sayur), FS (Fesese Sapi), FK (Feses Kerbau) dan FKu (Feses Kuda)

Sebagaimana yang ditunjukkan pada gambar 4.2 perlakuan FK menghasilkan volume gas yang paling tinggi. Namun, jika dilihat pada tabel 4.2 perlakuan feses sapi (FS) menunjukkan hasil nyala lebih lama yakni selama 13 detik dibandingkan perlakuan lainnya, SS 0 detik, FK 6 detik dan Fku 3 detik. Uji nyala pada perlakuan yang digunakan dapat dilihat hasilnya sebagaimana terdapat pada gambar 4.3.

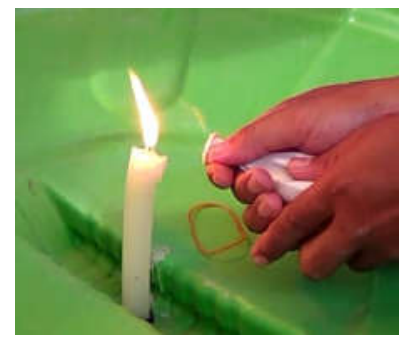

Gambar 4.3 Uji bakar

Uji nyala api yang telah dilakukan didapatkan hasil bahwa nyala api sebagian berwarna biru ketika ditempelkan pada nyala api lilin, sudah seperti nyala api biogas yang memiliki kandungan gas metana berwarna biru. Menurut Agarry (2012) seharusnya biogas berwarna biru sepenuhnya, namun kemungkinan perubahan warna api menjadi sedikit merah dapat disebabkan oleh adanya sedikit kadar gas $\mathrm{CO}_{2}$ yang masih terkandung sebagai impuritas dalam biogas yang dihasilkan.

Setiap perlakuan yang diuji pada penelitian ini menghasilkan gas metan yang masih tergolong rendah bahkan tidak ada, sebagaimana yang ditunjukkan terdapat pada lampiran 4. Rendahnya gas metan yang dihasilkan dapat dipengaruhi oleh banyak hal salah satunya suhu, banyaknya gas $\mathrm{CO}_{2}$ daripada $\mathrm{CH}_{4}$ dan kondisi $\mathrm{pH}$. Sebagaimana yang diungkapkan Suyitno et al. (2010) dalam buku teknologi biogas, ada 3 bakteri penting yang membantu proses pembentukan biogas dan masingmasing bakteri memiliki standar suhu optimum dalam produksi biogas. Adapun bakteri yang dimaksud ialah psycrophilic dengan suhu optimum $15-18{ }^{\circ} \mathrm{C}$, bakteri mesophilic $35-45{ }^{\circ} \mathrm{C}$ dan bakteri thermophilic $53-55{ }^{\circ} \mathrm{C}$. Sementara ratarata suhu yang diperoleh dari penelitian ini $28^{\circ} \mathrm{C}$.

Selain itu, ada perlakuan yang menujukkan hasil volume gas tinggi namun, waktu nyalanya rendah, sebagaimana pada perlakuan feses kerbau (FK). Mukhlis et al. (2017), mengatakan bila kadar $\mathrm{CH}_{4}$ tinggi maka biogas tersebut akan memiliki nilai kalor yang tinggi. Sebaliknya jika kadar $\mathrm{CO}_{2}$ yang tinggi maka akan mengakibatkan nilai kalor biogas tersebut rendah. Pernyataan Mukhlis et al. (2017) dapat disimpulkan bahwa tingginya volume biogas yang dihasilkan pada perlakuan feses kerbau tidak berkorelasi dengan kandungan metan dikarenakan kandungan $\mathrm{CO}_{2}$ yang mendominasi sebagaimana pernyataan Mukhlis et al. (2017). Sehingga berpengaruh pada waktu nyala api yang lebih rendah. Sama halnya yang diungkapkan Murjito (2008), jika waktu nyala api yang dihasilkan pada proses fermentasi biogas sebentar maka volume banyak mengandung gas $\mathrm{CO}_{2}$ dibanding gas $\mathrm{CH}_{4}$, begitupun sebaliknya. Hal ini dapat dilihat pada tabel 4.1 yang mana volume gas tertinggi dihasilkan oleh feses kerbau (FK). Namun, hasil nyala waktu paling lama dihasilkan dari perlakuan feses sapi (FS).

\section{Kesimpulan}

Adapun kesimpulan yang dapat ditarik dari penelitian ini yaitu:

1. Terdapat perbedaan efektifitas dari berbagai jenis perlakuan yang digunakan dengan ratarata volume total paling tertinggi dihasilkan pada perlakuan FK (feses kerbau) yaitu 75 $\mathrm{cm}^{3}$. Sementara pada uji nyala dihasilkan pada FS (feses sapi) selama 13 detik. Namun, meskipun secara volume gas tertinggi dihasilkan oleh perlakuan feses kerbau namun pada uji nyala tidak lama karena kandungan gas $\mathrm{CO}_{2}$ (karbondioksida) lebih banyak dari gas $\mathrm{CH}_{4}$ (metan).

2. Perlakuan feses sapi (FS) lebih efektif dengan menghasilkan waktu nyala lebih lama yakni selama 13 detik Efektifitas biogas dilihat dilihat lama waktu nyala yang dihasilkan yakni volume dan uji bakar. Berdasarkan hasil uji volume melalui pengukuran balon yang berisi gas didapatkan hasil yakni perlakuan SS 47 $\mathrm{cm}^{3}$, FS $45 \mathrm{~cm}^{3}$ FK $75 \mathrm{~cm}^{3}$ Fku $53 \mathrm{~cm}^{3}$. Dan nilai ini menunjukkan tidak adanya signifikansi hasil. Sementara dari hasil uji nyala perlakuan FS (Feses Sapi) memilik waktu nyala dengan rata-rata lebih lama yaitu 13 detik dibandingkan perlakuan lainnya, SS 0 detik, FK 6 detik dan Fku 3 detik.

\section{Saran}

Perlu dilakukan penelitian lanjutan dengan menggunakan metode, peralatan uji biogas yang lebih terkontrol seperti temperatur agar tetap stabil. Selain itu perlu adanya tambahan substrat untuk meningkatkan efektifitas produksi biogas yang dihasilkan. 


\section{DAFTAR PUSTAKA}

Abbasi, T., S. M. Tauseef,andS. A. Abbasi. 2012. Biogas Energy. Springer Briefs in Environmental Science: New York.

Adityawarman, A.C.,Salundik, dan Mara, C. 2015. Pengolahan Limbah Ternak Sapi Secara Sederhana Di Desa Pattalassary Kabupaten Sinjai Sulawesi Selatan. Jurnal Ilmu Produksi dan Teknologi Hasil Peternakan.

Agustina, Sari. 2013. Ekstraksi Senyawa Organik. Palembang

Al Seadi, T., D.Rutz, H. Prassl, M. Köttner, T. Finsterwalder, S. Volk, and R. Janssen.2008. Biogas Handbook. University of Southern Denmark

Agarry, S.E., 2012. Comparison of Biogas production from Cow dung and Pig dung under Mesophilic condition . page 21.

Bambang Subali, 2010. Analisis Statistika Menggunakan program SPSS Aplikasinya dalam rancangan acak lengkap. Yogyakarta

Dewi, M. H, I. Muchlis, L. Nur'aini dan M. Rizky. 2012. Pembuatan Biodegester Dengan Uji Coba Kotoran Sapi Sebagai Bahan Baku. Surakarta

Elinur, dkk. 2010. "Perkembangan Konsumsi Dan Penyediaan Energi Dalam Perekonomian Indonesia". Indonesian Journal of Agricultural Economics.Vol 2(1):98-100.

Firdaus, U.I.,2009. Biogas Energi Yang Baik Untuk Dikembangkan Di Lampung.

Lampung Google.com. The ruminant digestive system.Diakses pada 15 Januari 2019

Gerardi, M. H. 2003. The microbiology of anaerobic digesters. John Wiley \& Sons, Inc:Pennsylvania

Hambali, Eriza. 2007. Teknologi Bioenergi. AgroMedia. Jakarta

Harsono, 2013. Aplikasi Biogas Sistem Jaringan Dari Kotoran Sapi Di Desa Bumijaya Kec, Anak Tuha Lampung Tengah Sebagai Energi Alternatif Yang Efektif. Jurusan Teknik Mesin,Universitas Lampung

I Made Mara dan Ida Bagus Alit. 2011 Analisa

Kualitas dan Kuantitas Biogas dari Kotoran Ternak. Mataram

Ir.Sulistiyo, 2014, Pengurangan Subsidi Bbm Fosil Sebagai Momentum Pengemban Energi Alternatif Jenis Biofuel

Juanda, Irfan, dan Nurdiana. 2011. Pengaruh Metode dan Lama Fermentasi terhadap Mutu MOL (Mikroorganisme Lokal).

Manurung R. 2004. Proses Anaerobik Sebagai Alternatif Untuk Mengolah Limbah Sawit. Universitas Sumatra Utara.
Murjito. 2008. Desain alat perangkap gas Methan pada sampah menjadi Biogas. Teknik Mesin Universitas Muhammadiyah Malang. Malang

Megawati dan Kendali Wongso Aji. 2015. Pengaruh Penambahan Em4 (Effective Microorganism-4) Pada Pembuatan Biogas Dari Eceng Gondok dan Rumen Sapi. Semarang.

Metcalf dan Eddy. 1979. Wastewater Engineering Treatment, Disposa, and Reuse $\left(2^{\text {nd }}\right.$ Edition). New York

Mujahidah, Mappiratu, dan Sikanna R. 2013.Kajian teknologi produksi biogas dari sampah basah rumah tangga. Jurnal of Natural Science.

Kementrian Energi dan Sumber Daya Mineral. 2013 Kajian Supply Demand Energi. Pusat Data Dan Teknologi Informasi Energi Dan Sumber Daya Mineral.

Kompas.2015.https://travel.kompas.com/read/2015 /03/30/180800127/Sumbawa Masa.Depan.NTB

Maryani S. (2016). Potensi Campuran Sayuran Dan Kotoran Sapi Sebagai Penghasil Biogas. Skripsi Program Studi Biologi.Malang

Rahayu, S. D. Purwaningsih dan Pujianto. 2009. Pemanfaatan Kotoran Ternak Sapi Sebagai Sumber Energi Alternatif Ramah Lingkungan Beserta Aspek Sosial Kulturalnya. Inotek

Rohmadi Ridlo. 2017. Dasar-dasar Fermentasi Anaerobik. BPPT. PTSEIK

Said, N. I., dan Wahjono, H. D., 2006. Teknologi Pengolahan Limbah Ternak Dengan Proses Biofilter Anaerob dan Aerob, BPPT, Jakarta.

N.I. 2007. Bioindustri: Penerapan Teknologi Fermentasi. Jakarta: PT Mediyatama Sarana Perkasa

Sanjaya, A. Haryanto, Tamrin. 2015.Produksi Biogas dari Campuran Kotoran Sapi dengan Kotoran Ayam, Jurnal Teknik Pertanian Lampung

Sundari E., Ellyta S., dan Riko R. 2012. Pembuatan Pupuk organic Cair Menggunakan Bioaktivator biosca dan EM4. Prosiding SNTK TOPI.

Sutrisno.2010. Pembuatan Biogas dari Bahan Sampah Sayuran (Kubis, Kankung dan Bayam).

Suyitno , Sujono A, Dharmanto. 2010.Teknologi Biogas: Pembuatan, Operasional, dan Pemanfaatan. Yogyakarta

Purwinda Iriani, Yanti Suprianti, Fitria Yulistiani. 2017. Fermentasi Anaerobik Biogas Dua Tahap Dengan Aklimatisasi dan Pengkondisian $\mathrm{pH}$ Fermentasi. Bandung 